\title{
Validation of an FFQ to assess dietary protein intake in type 2 diabetic subjects attending primary health-care services in Mali
}

\author{
A Coulibaly, H Turgeon O'Brien and I Galibois* \\ Département des Sciences des Aliments et de Nutrition, Faculté des Sciences de l'Agriculture et de \\ I'Alimentation, Université Laval, Québec (QC), Canada G1K 7P4
}

Submitted 19 June 2007: Accepted 18 April 2008: First published online 12 June 2008

\begin{abstract}
Objective: To validate a 53-item quantitative FFQ (QFFQ) for the assessment of dietary protein intake in type 2 diabetic outpatients in Bamako, Mali.

Design: Consumption of protein-containing foods over the week preceding the interview was measured with a $7 \mathrm{~d}$ QFFQ and compared with intakes measured with 48-h recalls.

Setting: Centre National de Lutte contre le Diabète.

Subjects: Seventeen male and forty female adults with type 2 diabetes.

Results: Correlation between protein intakes estimated using the QFFQ and $48 \mathrm{~h}$ recalls was $0.63(P<0.0001)$. There was no significant difference between the two methods concerning the total protein daily intakes and intakes per kilogram of body weight. The QFFQ indicated that foods of animal origin were a lesser source of protein. Animal protein intake did not differ between men and women but sources did. In men, the main sources were beef $(54 \%$ of total animal protein), fish (15\%) and milk powder ( $8 \%)$. In women, the principal sources were fish (28\%), beef (20\%) and birds (13\%). In contrast, plant protein intake was significantly higher in men than in women $(P=0 \cdot 01)$, but the same plant foods contributed in similar proportions for both genders, rice being by far the greatest source ( $47 \%$ of plant protein in men, $53 \%$ in women).

Conclusion: The QFFQ developed in this study is a valid tool to evaluate dietary protein intakes in Malian diabetic subjects. While the total protein intakes were low in both men and women, differences in choices and amounts of protein food sources were shown.
\end{abstract}

\author{
Keywords \\ Type 2 diabetes \\ Protein intake \\ Food-frequency questionnaire \\ $48 \mathrm{~h}$ dietary recall
}

Type 2 diabetes mellitus is an important health issue worldwide. Black Africans living in rural and urban regions of Africa are no exception ${ }^{(1)}$. In Mali, the estimated number of people afflicted with diabetes was 140000 in 2000, and it is expected to rise to 405000 by $2030^{(2)}$. The increasing prevalence of type 2 diabetes in sub-Saharan African regions can be partly ascribed to modernisation and adoption of Western lifestyle with an associated increase of energy-dense diets, reduced physical activity and obesity ${ }^{(3)}$.

Nutrition therapy is an integral part of the treatment of diabetes mellitus and patient self-management ${ }^{(4-8)}$. Classically, more emphasis has been placed on the relative amounts and types of carbohydrate and fat to include in the diet ${ }^{(5-10)}$, but some studies have also reported beneficial effects of increasing dietary protein in type 2 diabetes $^{(11-13)}$. This could be related to the fact that proteins do not increase plasma glucose concentrations in subjects with controlled diabetes, while ingested proteins are just as potent a stimulant of insulin secretion as carbohydrates $^{(14-17)}$. Thus, food proteins could contribute to an improvement in metabolic control. In the general population, the WHO/FAO recommend protein intake to account for $10-15 \%$ of the total energy ${ }^{(9)}$. The dietary intake of protein for individuals with diabetes and normal renal function should range between $15 \%$ and $20 \%$ of the total energy, according to the American Diabetes Association $^{(5,6)}$.

In sub-Saharan Africa, particularly in Mali, it has been reported that the availability of protein per capita for the general population was $60 \mathrm{~g} / \mathrm{d}^{(18,19)}$ in contrast with the USA where the food supply provided an average of $113 \mathrm{~g}$ per capita per day in $2004^{(20)}$. In addition, Mali is currently affected by a strong devaluation of its currency (CFA franc). This places the population at great risk as it has reached a limit in its capacity for adaptation, which includes not only the quality but also the quantity of food consumed $^{(21)}$. These factors may indicate that the protein 
intake of a large number of Malian diabetic patients could be inadequate, in terms of both amount and quality.

In low-income countries, there is a lack of costeffective dietary assessment methods ${ }^{(22)}$; therefore it is necessary to develop quantitative methods to assess food and nutrient intake. The FFQ is currently the method most often used for assessing dietary intake in large epidemiological studies in industrialised countries ${ }^{(22)}$. It represents a practical and cost-effective alternative to diet recalls and diet histories ${ }^{(23)}$.

The aim of the present study was to conduct a nutritional survey in a group of type 2 diabetic patients in Mali in order to validate a $7 \mathrm{~d}$ FFQ developed to quantify and characterise the usual dietary protein intake.

\section{Methods}

A detailed description of the study methods has been presented elsewhere ${ }^{(24)}$; therefore, only a brief summary is given here.

\section{Subjects and ethics}

The study was undertaken in a primary health-care service for diabetes: the Centre National de lutte contre le Diabète (CNLD) in Bamako, Mali.

Fifty-seven adult Malians aged between 25 and 75 years, diagnosed with type 2 diabetes and not treated with insulin, were included in the study. Participants were among the outpatients who attended primary health-care services. The patients visiting the clinic received information from their physician. In order to facilitate patients' adherence in the study, physicians were in charge of explaining the study protocol and verifying the eligibility criteria, which were checked again by a member of the research team (A.C.). The study was approved by the research ethical committee of Laval University. A written informed consent was obtained from subjects prior to their inclusion in the study.

The sample comprised more women than men (forty females $v$. seventeen males), largely reflecting the composition of the CNLD clientele as it was observed on the days of data collection. However, it could not be determined whether this is representative of the actual type 2 diabetic adult population in Mali.

\section{Study design}

This study was conducted on site over a 5-month period, between May and October 2005, corresponding to the wet season in Mali. Each subject individually met A.C. and the interviews were conducted in a local dialect, Bamana. The first interview comprised anthropometric measurements, a general questionnaire, a $7 \mathrm{~d}$ quantitative FFQ (QFFQ) and a dietary recall. Most subjects came back during the following weeks for another interview with A.C. to complete a second dietary recall.

\section{Antbropometric measurements and general questionnaire}

Weight was measured with light clothing on a digital scale to the nearest $0 \cdot 1 \mathrm{~kg}$; standing height was measured without shoes using a wooden measuring board and tape with a precision of $0.1 \mathrm{~cm}$. The BMI was then calculated by dividing weight $(\mathrm{kg})$ by the square of height $(\mathrm{m})$.

After anthropometric measurements were taken, each participant was submitted to a general questionnaire to collect information on diabetes duration and treatment and on sociodemographic characteristics.

\section{Dietary recalls}

In the present study, participants were asked to recall their previous $48 \mathrm{~h}$ intake of food and beverages. It was shown that a $48 \mathrm{~h}$ recall is able to rank participants appropriately with respect to most nutrients and many foods, and is superior to a single $24 \mathrm{~h}$ recall ${ }^{(25)}$. All participants completed one ( $n$ 14) or two $(n 43) 48 \mathrm{~h}$ recalls. The nutrient content was analysed using the nutritional analysis software NUTRIFIQ developed at the Département des Sciences des Aliments et de Nutrition at Laval University in Québec, Canada, and based on the 2001 Canadian Nutrient File ${ }^{(26)}$. To complete the database, nutritive values of foods from the Malian Food Composition Table ${ }^{(27)}$ were added to the Canadian Nutrient File.

\section{The 7 d quantitative $F F Q$}

The QFFQ developed for the present study covered the amount of all protein-containing foods consumed during the $7 \mathrm{~d}$ preceding the interview. Using the Food Composition Table for Mali ${ }^{(27)}$ and the Food Composition Tables for use in Africa ${ }^{(28)}$, most food items and dishes consumed in Mali that were a source of protein (that is, supplying at least $1 \mathrm{~g}$ protein per $100 \mathrm{~g}$ ) were identified. The QFFQ was pre-tested with a few diabetic patients ( $n$ 5) in order to ensure completeness and functionality of the questionnaire. These patients were not included in the actual study.

The QFFQ contained a list of fifty-three food items divided in two main categories: animal proteins and plant proteins. The animal protein group comprised meat, offal, poultry, fish, eggs and milk, as well as combination dishes containing these foods, while the plant protein group included dishes of beans, soya, peas, groundnut, rice, maize, sorghum, millet, wheat and tubers. Also, openended questions on other protein foods consumed were included at the end of the QFFQ. Food models and usual utensils were used to help participants assess the amounts eaten. In Mali, a significant proportion of daily intake is made up of foods and beverages bought from street vendors. When participants were asked to describe the size of the portions they ate, they would often refer to the price they paid. Local street foods were also purchased from vendors by A.C. in order to determine the weight of the portion by the price paid. Portion sizes of foods 
recorded in household measures were also converted to weight equivalents.

For each food in the list, a protein conversion factor was derived from food composition tables. The conversion factor is a number between $0 \cdot 01$ and $1 \cdot 00$, which represents the amount of protein in $1 \mathrm{~g}$ of food. For each participant, the protein content of the average portion consumed on a daily basis was calculated by multiplying the weight of the portion (in $\mathrm{g}$ ) by the conversion factor. A summation was made for the animal protein foods and the plant protein foods, as well as for the total daily protein intake.

Of the fifty-seven participants included in this study, two did not complete the FFQ; so the dietary protein intakes from the QFFQ were calculated for fifty-five participants.

\section{Biochemical analyses}

In the days following the first interview, the subjects were asked to go to a private laboratory of biomedical analyses (Laboratoire ALGI) in Bamako to undergo a blood test. Fasting venous blood samples were collected from patients using tubes containing ethylenediaminetetraacetic acid (EDTA) for glycosylated haemoglobin (HbA1c) analysis, and into tubes containing sodium fluoride for glucose analysis. Blood sample collections and the analyses were carried out directly in the private laboratory. Of the fifty-seven participants included in this study, seven failed to go to the laboratory and did not undergo the blood sampling.

Glucose levels were measured by enzymatic methods using a glucose RTU kit from Biomerieux. HbA1c was measured using the D-10 automat system of BIO-RAD, an HPLC system that operates without pre-treatment of the sample and with a restricted intervention by the user. The D-10 technique for HbA1c is certified by the 'National Glycohemoglobin Standardization Program' (NGSP), and has proven its traceability compared to the reference method of the 'Diabetes Control and Complications Trial, (29)

At each meeting with A.C. in the CNLD, capillary fasting blood glucose was also measured for each participant using a blood glucose meter and test strips from Ascencia Contour, Bayer.

\section{Statistical analysis}

Statistical analyses were performed using SAS release 9•1 (SAS Inc., Cary, NC, USA). The normality of data was tested before statistical analyses. Results are expressed as mean and SD unless otherwise stated. Comparisons between groups were undertaken using independent sample Student's $t$-tests. Comparisons were also made between the two methods using the paired $t$-test. Pearson's correlation coefficients were calculated to measure the association between the two dietary intake methods. Statistical significance was set at $P<0 \cdot 05$.

\section{Results}

The mean age of the participants was 54.5 (SD 9.4) years and their diabetes duration was 3.5 (SD 3.8) years. More than three-quarters of the subjects were married. In subjects' households, the meals were shared by an average of seventeen family members. About a quarter of the subjects were employed. Forty-two per cent did not have any schooling; approximately $16 \%$ went to university, while $42 \%$ of subjects had reached either a primary or a lycée/ college education level.

Only one-tenth of participants took no medication and managed their diabetes only with diet, whereas one-third took medicinal plants with or without oral hypoglycaemic agents. About half of the subjects who took oral hypoglycaemic agents used drugs of the sulfonylurea class, mainly Amarel ${ }^{\circledR}$, Glucophage ${ }^{\circledR}$, Hemidaonil ${ }^{\circledR}$ and Daonil ${ }^{\circledR}$. Regarding frequency of intake, $17 \cdot 5 \%$ of the subjects took the oral hypoglycaemic agents once per day, 35\% took them twice, 30\% took them three times per day and finally, only $2 \%$ of subjects took these drugs four times per day. When used, the medicinal plants were mainly taken in the form of infusion. More than threequarters of the users took them daily; only two subjects took them on a weekly basis and one only occasionally.

Concerning dietary advices, all participants, except two, said that they had received nutritional counselling related to their diabetes. Un-individualised nutritional advice given to patients at the CNLD focuses on three essential points which are: (i) foods to be avoided: sugar, banana, cream, condensed milk, cake, dried fruits, honey, fruits with syrup, fruit juice; (ii) foods to be eaten in restricted amounts, such as meat and fish, no more than $250 \mathrm{~g} / \mathrm{d}$; and starchy foods to be measured with a $400 \mathrm{ml}$ bowl: white rice, steamed rice, fonio (an African cereal crop low in protein), potato, yam, millet, corn, peas, beans; and (iii) vegetables allowed without measurement. Other advice were related to lifestyle habits: $30 \mathrm{~min}$ of physical activity per day and weaning from smoking were recommended.

Clinical characteristics and energy and macronutrient intakes of participants according to the $48 \mathrm{~h}$ recalls are presented for each gender in Table 1 . There was no significant difference between men and women for age and weight. BMI was larger for women than for men. On the contrary, height and daily intakes of energy were significantly higher in men than in women. However, the contribution of macronutrients expressed as a percentage of total energy was not different between men and women. Fasting blood glucose values were also similar for both genders. Although HbA1c tended to be higher in men than in women, the difference was not statistically significant.

Protein intake estimates obtained with the $48 \mathrm{~h}$ recalls and with the QFFQ were compared. Using Pearson's test of correlation, positive and significant correlations were 
Table 1 Anthropometric characteristics, metabolic control and dietary intakes of participants according to $24 \mathrm{~h}$ dietary recalls $(n 57)$

\begin{tabular}{|c|c|c|c|c|c|}
\hline \multirow[b]{2}{*}{ Variable } & \multicolumn{2}{|c|}{ Men (n 17) } & \multicolumn{2}{|c|}{ Women (n 40) } & \multirow[b]{2}{*}{$P$ value } \\
\hline & Mean & SD & Mean & SD & \\
\hline Age (years) & $56 \cdot 4$ & $10 \cdot 6$ & $53 \cdot 7$ & 8.9 & NS \\
\hline Height $(\mathrm{m})$ & $1 \cdot 70$ & 0.07 & $1 \cdot 63$ & 0.06 & 0.0004 \\
\hline Weight (kg) & $69 \cdot 7$ & $9 \cdot 7$ & $72 \cdot 4$ & $16 \cdot 7$ & NS \\
\hline BMI $\left(\mathrm{kg} / \mathrm{m}^{2}\right)$ & $24 \cdot 1$ & $3 \cdot 8$ & 27 & $5 \cdot 3$ & 0.043 \\
\hline $\mathrm{HbA1c}(\%)$ & $8 \cdot 2$ & $3 \cdot 1$ & $7 \cdot 6$ & $2 \cdot 1$ & NS \\
\hline Fasting plasma glucose $(\mathrm{mmol} / \mathrm{l})$ & $7 \cdot 3$ & $3 \cdot 4$ & $7 \cdot 2$ & $3 \cdot 7$ & NS \\
\hline Capillary fasting blood glucose $(\mathrm{mmol} / \mathrm{l})$ & $7 \cdot 7$ & $2 \cdot 9$ & $7 \cdot 9$ & $2 \cdot 7$ & NS \\
\hline Energy (kJ) & 9792 & 2382 & 6984 & 2332 & $0 \cdot 0001$ \\
\hline Carbohydrate (\% of energy) & 57 & 9 & 56 & 8 & NS \\
\hline Fat (\% of energy) & 31 & 8 & 30 & 8 & NS \\
\hline Protein (\% of energy) & 12 & 3 & 12 & 2 & NS \\
\hline
\end{tabular}

HbA1c, glycosylated haemoglobin.

$P<0.05$.

Table 2 Daily protein intake of participants by gender according to the $48 \mathrm{~h}$ recalls $(n 57)$ and the QFFQ $(n 55)$

\begin{tabular}{|c|c|c|c|c|c|}
\hline \multirow[b]{2}{*}{ Variable } & \multicolumn{2}{|c|}{$48 \mathrm{~h}$ recalls } & \multicolumn{2}{|c|}{ QFFQ } & \multirow[b]{2}{*}{$P$ valuet } \\
\hline & Mean & SD & Mean & SD & \\
\hline \multicolumn{6}{|l|}{ Daily intake } \\
\hline All subjects & 58 & 26 & 60 & 22 & NS \\
\hline Men‡ & 73 & 27 & 68 & 23 & NS \\
\hline Women§ & $51^{*}$ & 24 & 56 & 20 & NS \\
\hline \multicolumn{6}{|c|}{ Intake per kg body weight } \\
\hline All subjects & $0 \cdot 8$ & 0.4 & 0.9 & 0.4 & NS \\
\hline Men & $1 \cdot 1$ & 0.4 & $1 \cdot 0$ & 0.4 & NS \\
\hline Women & $0 \cdot 7^{*}$ & $0 \cdot 4$ & $0 \cdot 8$ & $0 \cdot 3$ & NS \\
\hline
\end{tabular}

*Significantly different from men $(P<0.01)$.

tSignificance of the difference between mean recall and quantitative FFQ (QFFQ).

$\ddagger n 17$ for dietary recall, $n 16$ for QFFQ

$\S n 40$ for dietary recall, $n 39$ for QFFQ.

found between daily protein intakes using the QFFQ and $48 \mathrm{~h}$ recalls (all subjects: $r=0.63, P<0.0001$; women: $r=0.61, P<0.0001$; men $r=0.59, P=0.02$ ). Results of the $t$-tests are shown in Table 2, where the total protein daily intakes and intakes per kilogram of body weight are also presented. There were no significant differences between the two methods.

The staple foods that were the predominant providers of protein in the diets of men and women according to the QFFQ are reported in Table 3. Concerning animal proteins, the total daily intake did not differ between men and women, but contributions of some food sources did. In men, the main sources of animal protein were in decreasing order: beef ( $54 \%$ of total animal protein), fish (15\%) and milk powder ( $8 \%)$. In women, the principal sources were fish (28\%), beef (20\%) and birds (chicken, guinea fowl, pigeon) (13\%). In absolute amounts, the daily intake of beef $(P=0 \cdot 04)$ was significantly higher in men than in women, while women consumed more milk curds than men $(P=0 \cdot 01)$. For plant proteins, the picture was somewhat different. Total daily intake was significantly higher in men than in women $(P=0 \cdot 01)$, but the same plant foods contributed in similar proportions to the total intake for both genders. Thus, rice was by far the largest source of plant protein ( $47 \%$ in men, $53 \%$ in women), followed by bread (12\% in men and women) and groundnut (11\% in men, $9 \%$ in women).

\section{Discussion}

In the context that information on the diet of Malian diabetic patients is scarce and considering that dietary protein could contribute to the improvement in blood glucose control, we developed an interviewer-administered QFFQ to measure the intakes of protein in the habitual diet of these subjects. The purpose of the present study was to validate this QFFQ in a group of type 2 diabetic patients attending a primary health-care service in Mali, using $48 \mathrm{~h}$ recalls as the reference method.

Results indicate that there were no significant differences in the intakes of protein evaluated with the QFFQ and the $48 \mathrm{~h}$ recalls. A significant positive correlation was found between the QFFQ and the $48 \mathrm{~h}$ dietary recalls for protein intake $(r=0 \cdot 63)$, which was within the expected range and similar to the findings of Rodriguez et $a l^{(30)}(r=0.53)$. It has been previously reported that the correlation coefficient of a nutrient should range from $0 \cdot 40$ to $0 \cdot 70$ in order to produce a good agreement between assessment methods ${ }^{(31,32)}$. Some studies on subjects without diabetes ${ }^{(33)}$ have found a higher $(r=0 \cdot 76)$, weaker or no correlation $^{(34,35)}$ in dietary protein. In adults with type 1 diabetes, Riley and Blizzard ${ }^{(36)}$ investigated the characteristics of a FFQ in measuring dietary intake. They have reported a weak correlation $(r=0 \cdot 38)$ for dietary proteins. This difference could be due to the reference method. They used $2 \mathrm{~d}$ weighed dietary records, while in our study the reference method was the $48 \mathrm{~h}$ recall.

Although we found positive and significant correlations and no significant difference in the daily intakes between the two dietary methods, only the $48 \mathrm{~h}$ recalls showed significant differences between men and women in total protein intake and in intake per kilogram of body weight. 
Table 3 Main sources of animal and plant protein in diets of type 2 diabetic men and women in Mali

\begin{tabular}{|c|c|c|c|c|c|c|c|c|c|c|}
\hline \multirow[b]{3}{*}{ Source } & \multicolumn{5}{|c|}{ Amount $(g / d)$} & \multicolumn{5}{|c|}{ Protein (g/d) } \\
\hline & \multicolumn{2}{|c|}{ Men $(n 16)$} & \multicolumn{2}{|c|}{ Women (n 39) } & \multirow[b]{2}{*}{$P$ value } & \multicolumn{2}{|c|}{ Men (n 16) } & \multicolumn{2}{|c|}{ Women (n 39) } & \multirow[b]{2}{*}{$P$ value } \\
\hline & Mean & SD & Mean & SD & & Mean & SD & Mean & SD & \\
\hline \multicolumn{11}{|l|}{ Animal protein } \\
\hline Beef & $48 \cdot 2$ & $54 \cdot 6$ & $17 \cdot 2$ & $21 \cdot 4$ & 0.04 & $13 \cdot 0$ & $14 \cdot 7$ & $4 \cdot 6$ & $5 \cdot 8$ & 0.04 \\
\hline Mutton & $4 \cdot 4$ & $11 \cdot 0$ & $3 \cdot 7$ & $9 \cdot 3$ & 0.82 & $1 \cdot 2$ & $3 \cdot 0$ & $1 \cdot 0$ & $2 \cdot 5$ & 0.82 \\
\hline Goat & 0.5 & $2 \cdot 1$ & $1 \cdot 9$ & $11 \cdot 4$ & 0.46 & 0.14 & 0.6 & 0.5 & $3 \cdot 1$ & 0.46 \\
\hline Offal & $1 \cdot 2$ & $3 \cdot 4$ & $2 \cdot 6$ & $6 \cdot 6$ & 0.52 & 0.3 & 0.9 & 0.6 & $1 \cdot 4$ & $0 \cdot 27$ \\
\hline Bird & $5 \cdot 1$ & $12 \cdot 0$ & $11 \cdot 1$ & $27 \cdot 8$ & 0.26 & $1 \cdot 4$ & $3 \cdot 2$ & $3 \cdot 0$ & $7 \cdot 5$ & 0.26 \\
\hline Fish & $13 \cdot 3$ & $10 \cdot 4$ & $24 \cdot 6$ & $38 \cdot 1$ & 0.09 & $3 \cdot 6$ & $2 \cdot 8$ & $6 \cdot 6$ & $10 \cdot 3$ & 0.09 \\
\hline Eggs & $0 \cdot 1^{a}$ & 0.4 & $0 \cdot 1^{a}$ & 0.2 & 0.99 & $1 \cdot 2$ & $3 \cdot 1$ & $1 \cdot 2$ & $1 \cdot 8$ & 0.99 \\
\hline Milk powder & $7 \cdot 5$ & $14 \cdot 3$ & $10 \cdot 0$ & $13 \cdot 1$ & 0.53 & $2 \cdot 0$ & $3 \cdot 7$ & $2 \cdot 6$ & $3 \cdot 4$ & 0.53 \\
\hline Liquid milk & $21 \cdot 9$ & $42 \cdot 0$ & $52 \cdot 4$ & $114 \cdot 5$ & $0 \cdot 15$ & 0.9 & $1 \cdot 7$ & $2 \cdot 1$ & $4 \cdot 7$ & $0 \cdot 15$ \\
\hline Milk curds & 0.0 & 0.0 & $18 \cdot 9$ & $45 \cdot 0$ & 0.01 & 0.0 & 0.0 & 0.7 & $1 \cdot 8$ & 0.01 \\
\hline Total & & & & & & 24 & 18 & 23 & 16 & NS \\
\hline \multicolumn{11}{|l|}{ Plant protein } \\
\hline Beans & $22 \cdot 3$ & $43 \cdot 3$ & $17 \cdot 0$ & $37 \cdot 8$ & 0.65 & $1 \cdot 6$ & $3 \cdot 0$ & $1 \cdot 3$ & $2 \cdot 8$ & 0.73 \\
\hline Groundnut & $24 \cdot 3$ & $26 \cdot 7$ & $17 \cdot 4$ & $24 \cdot 9$ & 0.36 & $4 \cdot 9$ & $5 \cdot 9$ & $3 \cdot 0$ & $3 \cdot 9$ & 0.25 \\
\hline Peanut sauce & $41 \cdot 7$ & $57 \cdot 0$ & $21 \cdot 5$ & $25 \cdot 6$ & $0 \cdot 19$ & $1 \cdot 2$ & $1 \cdot 7$ & 0.6 & $0 \cdot 8$ & $0 \cdot 19$ \\
\hline Rice & $700 \cdot 7$ & $336 \cdot 1$ & $594 \cdot 3$ & $318 \cdot 8$ & 0.27 & $20 \cdot 6$ & $9 \cdot 4$ & $17 \cdot 5$ & $9 \cdot 6$ & 0.28 \\
\hline Maize & $134 \cdot 5$ & $224 \cdot 5$ & $49 \cdot 0$ & $110 \cdot 8$ & 0.16 & $2 \cdot 9$ & $4 \cdot 7$ & $1 \cdot 1$ & $2 \cdot 2$ & 0.14 \\
\hline Sorghum & $48 \cdot 2$ & $178 \cdot 2$ & $125 \cdot 5$ & $237 \cdot 7$ & 0.25 & $1 \cdot 1$ & $3 \cdot 8$ & $2 \cdot 9$ & $5 \cdot 3$ & 0.22 \\
\hline Millet & $150 \cdot 4$ & $289 \cdot 1$ & $59 \cdot 1$ & $148 \cdot 1$ & 0.24 & $3 \cdot 3$ & $6 \cdot 8$ & $1 \cdot 3$ & $3 \cdot 3$ & 0.27 \\
\hline Macaroni & $72 \cdot 8$ & $107 \cdot 8$ & $33 \cdot 1$ & $62 \cdot 3$ & $0 \cdot 18$ & $1 \cdot 4$ & $2 \cdot 1$ & $0 \cdot 7$ & $1 \cdot 2$ & $0 \cdot 18$ \\
\hline Bread & $74 \cdot 8$ & $61 \cdot 1$ & $56 \cdot 0$ & $57 \cdot 6$ & 0.28 & $5 \cdot 2$ & $4 \cdot 2$ & $3 \cdot 9$ & $4 \cdot 0$ & 0.28 \\
\hline Yam with meat & $30 \cdot 3$ & $53 \cdot 2$ & $22 \cdot 7$ & $45 \cdot 8$ & 0.59 & $0 \cdot 3$ & 0.5 & $0 \cdot 2$ & $0 \cdot 4$ & 0.59 \\
\hline Boiled yam & $8 \cdot 5$ & $23 \cdot 2$ & $5 \cdot 3$ & $13 \cdot 5$ & 0.61 & 0.4 & $1 \cdot 2$ & $0 \cdot 3$ & 0.7 & 0.61 \\
\hline Cassava & $18 \cdot 7$ & $64 \cdot 0$ & $4 \cdot 1$ & $10 \cdot 1$ & 0.38 & 0.7 & $2 \cdot 6$ & $0 \cdot 2$ & $0 \cdot 4$ & 0.38 \\
\hline Potato & $12 \cdot 0$ & $26 \cdot 0$ & $16 \cdot 3$ & $33 \cdot 6$ & 0.65 & $0 \cdot 2$ & 0.5 & 0.3 & $0 \cdot 7$ & 0.65 \\
\hline Sweet potato & $6 \cdot 6$ & $24 \cdot 9$ & $1 \cdot 1$ & $4 \cdot 3$ & 0.4 & 0.1 & 0.2 & 0.01 & 0.04 & 0.4 \\
\hline Total & & & & & & 44 & 16 & 33 & 14 & 0.01 \\
\hline
\end{tabular}

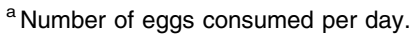

This might be due to under- and overestimation of intakes, depending on the dietary assessment method. It has been shown that FFQ can both under- and overestimate the intakes of specific nutrients ${ }^{(34)}$. In fact, many validation studies have reported that FFQ, when compared to food records or $24 \mathrm{~h}$ recalls, overestimate nutrient intakes ${ }^{(22,23,30,33,37)}$. In contrast, other studies have reported that FFQ did not systematically overestimate nutrient intakes ${ }^{(34,38-40)}$.

Regardless of dietary methods, the present study showed that dietary protein intakes in a group of type 2 diabetic men and women in Mali were similar to what is observed for protein availability (around $60 \mathrm{~g}$ per capita per day) in the diet of the general Malian population ${ }^{(18,19)}$. They were also quite similar to the dietary protein intakes of South African black men and women with type 2 diabetes (63 and $50 \mathrm{~g} / \mathrm{d}$, respectively) ${ }^{(41)}$, but lower than that of Ghanaian type 2 diabetics $(81 \mathrm{~g} / \mathrm{d})^{(42)}$. Compared to the protein availability of the US population (113g per capita per day) in $2004^{(20)}$, the lower protein intake of the participants in this study could be due to the reduced financial means and to the large number of family members, which could limit the access to excellent sources of protein such as meat and fish. In fact, Torheim et $a l^{(22)}$ have reported in their study conducted in a Malian village that meat and fish were rarely eaten.
The fact that food patterns in Mali are seasonal ${ }^{(19,22)}$ could explain the low intake of protein by the diabetic patients. Indeed, our study was conducted during the wet season, which is not the period of harvest, and hence staple foods such as cereals were not abundant. The low protein intake could also be due to the fact that patients were sometimes given conflicting advice with respect to the type of foods they were allowed to eat, and they generally appeared to have little understanding of portion sizes. We found that the main provider of proteins in their diet was plant protein, which was also shown in other studies $^{(18,19)}$. But at the same time, as doctors and nurses had counselled them to eat less food that was rich in starch, our subjects may have under-reported their plant food intake to show their adherence to nutritional counselling. Although dietary carbohydrate is the major contributor to postprandial glucose concentration, it is an important source of energy, water-soluble vitamins and minerals, and fibre ${ }^{(5-7)}$. Hence, low-carbohydrate diets are not recommended in the management of diabetes. The amount of carbohydrate ingested is usually the primary determinant of postprandial response, but the type of carbohydrate also affects this response $\mathrm{e}^{(5-7)}$. As carbohydrate-containing plant foods are the main provider of dietary protein in Malian diabetic patients, they should be advised to give preference to plant foods such as legumes 
that could provide more protein than rice or maize, and that could also provide more fibre, which is beneficial in type 2 diabetes ${ }^{(5-7)}$. Moreover, an experimental study in subjects with type 2 diabetes reported that compared to potatoes, dried peas induced a delayed and smaller increase in postprandial plasma glucose, supporting the suggestion that type 2 diabetic patients should increase their consumption of low-glycaemic, high-fibre foods at the expense of high-glycaemic, low-fibre foods ${ }^{(43)}$.

We should also keep in mind that Mali is one of the poorest countries in Africa and with the 1994 devaluation of the currency, a great impoverishment of the population was observed. The continuing impoverishment of the Malian population, the impact of large family sizes and food consumption units, and the cost of diabetes treatment pose a major challenge to patients who cannot afford more than staple foods, which are mainly plant food.

The higher consumption of dietary protein and beef in men compared to women can be explained by sociocultural conditions prevailing in Mali such as polygamy, number of family members and the women's position in the family. In fact, women are generally housewives, with men being the main financial providers. This leaves women in a lower economic situation. Men have privileged access to food and, as seen here, have more beef in their diet than women. Moreover, women must at first satisfy their husband and children's dietary intake in order to be well regarded by their family. The presence of street food consumption in $\mathrm{Mali}^{(21,44)}$ could also explain the higher consumption of animal protein and beef in men. The fact that men have financial resources could allow them to buy street foods rich in protein such as meat, fish and eggs to supplement their dietary protein intake.

In patients with type 2 diabetes, it was reported that the simultaneous ingestion of glucose with protein in test meals significantly decreased the glycaemic response, as compared with glucose taken alone ${ }^{(45)}$. Other single-meal studies confirmed that protein foods have a modest impact on blood glucose but a significant effect on insulin secretion $^{(14,15)}$ in type 2 diabetic subjects. In addition, clinical studies have shown that an increase in dietary protein improved the metabolic control in type 2 diabetes, albeit in the context of a weight-loss diet ${ }^{(11)}$ or without weight loss ${ }^{(46)}$.

Considering these potential beneficial effects of dietary protein in type 2 diabetes, future studies should be conducted to evaluate the effect of a nutritional intervention in Malian type 2 diabetic patients without nephropathy that would aim to improve their protein intake. Also, as dietary habits depend on the time of the year, nutrition surveys should be repeated in other seasons and with larger and more representative samples to confirm the assessment of usual protein intake with the QFFQ. Finally, dietary protein intake could be validated using biomarkers such as urinary nitrogen.

\section{Conclusion}

In conclusion, although our study presents some limitations, we found that the QFFQ developed in the present study is a valid and useful tool to estimate the average daily protein intakes of type 2 diabetic patients in Mali. We also found that diabetic patients need to receive more nutrition counselling and many patients need to increase their protein intake, particularly women. However, it will be necessary to conduct nutritional surveys with larger samples to verify the actual intake of the type 2 diabetic population in Mali.

\section{Acknowledgements}

Source of funding: This work received financial support from Programme Canadien des bourses de la francophonie.

Conflict of interest: No conflict of interest.

Author contributions: A.C. is a candidate for a $\mathrm{PhD}$ in nutrition at Université Laval. This paper is a part of her thesis work. I.G. is her research director, and H.T.O'B. is her co-director.

Acknowledgements: We thank Dr Niantao, Boukenem, Konake Kadidia, nurses of the CNLD, and all participants of this study.

\section{References}

1. Osei K, Schuster DP, Amoah AGB \& Owusu SK (2003) Pathogenesis of type 1 and type 2 diabetes mellitus in subSaharan Africa: implications for transitional populations. J Cardiovasc Risk 10, 85-96.

2. World Health Organization (2007) Facts and figures. http:// www.who.int/diabetes/facts/world_figures/en/index1.html (accessed May 2007).

3. Ostbye T, Welby TJ, Prior IAM, Salmond CE \& Stokes YM (1989) Type 2 (non insulin dependent diabetes) migration and westernization; the Tokelau Island study. Diabetologia 32, 585-590.

4. Amend A, Melkus GD, Chyun DA, Galasso P \& WylieRosett J (2007) Validation of dietary intake data in black women with type 2 diabetes. J Am Diet Assoc 107, 112-117.

5. Bantle JP, Wylie-Rosett J, Albright AL et al. (2006) Nutrition recommendations and interventions for diabetes -2006 . A position statement of the American Diabetes Association. Diabetes Care 29, 2140-2157.

6. Bantle JP, Wylie-Rosett J, Albright AL et al. (2007) Nutrition recommendations and interventions for diabetes. A position statement of the American Diabetes Association. Diabetes Care 30, S48-S65.

7. American Diabetes Association (2006) Standards of medical care in diabetes 2006. Diabetes Care 29, S4-S42.

8. Canadian Diabetes Association (2003) Clinical practice guidelines for the prevention and management of diabetes in Canada. Expert Committee. Can J Diabetes 27, S1-S152.

9. World Health Organization (2003) Diet, Nutrition and the Prevention of Chronic Diseases. Joint WHO/FAO Expert Consultation. Geneva: WHO. 
10. Ha TKK \& Lean MEJ (1998) Recommendations for the nutritional management of patients with diabetes mellitus. Eur J Clin Nutr 52, 467-481.

11. Parker B, Noakes M, Luscombe N \& Clifton P (2002) Effect of high-protein, high-monounsaturated fat weight loss diet on glycemic control and lipid levels in type 2 diabetes. Diabetes Care 25, 425-430.

12. Gannon MC, Nuttall FQ, Saeed A, Jordan K \& Hoover H (2003) An increase in dietary protein improves the blood glucose response in persons with type 2 diabetes. $\mathrm{Am} \mathrm{J}$ Clin Nutr 78, 734-741.

13. Gannon MC \& Nuttall FQ (2004) Effect of a high-protein, low-carbohydrate diet on blood glucose control in people with type 2 diabetes. Diabetes 53, 2375-2382.

14. Gannon MC, Nuttall FQ, Grant CT, Ercan-Fang S \& ErcanFang N (1998) Stimulation of insulin secretion by fructose ingested with protein in people with untreated type 2 diabetes. Diabetes Care 21, 16-22.

15. Saeed A, Jones SA, Nuttall FQ \& Gannon MC (2002) A fasting-induced decrease in plasma glucose concentration does not affect the insulin response to ingested protein in people with type 2 diabetes. Metabolism 51, 1027-1033.

16. Franz MJ, Bantle JP, Beebe CA et al. (2002) Evidence-based nutrition principles and recommendations for the treatment and prevention of diabetes and related complications. Diabetes Care 25, 148-198.

17. Franz MJ (2004) Evidence-based medical nutrition therapy for diabetes. Nutr Clin Pract 19, 137-144.

18. Honfoga BG \& Van Den Boom GJM (2003) Foodconsumption patterns in central West Africa, 1961 to 2000, and challenges to combating malnutrition. Food Nutr Bull 24, 167-181.

19. Food and Agriculture Organization (1999) Aperçus nutritionnels par pays-Mali. http://www.fao.org/ag/agn/nutrition/ mal-f.stm (accessed May 2007).

20. US Department of Agriculture (2007) Nutrient Content of the US food supply, 1909-2004. A summary report. http://www.cnpp.usda.gov/USFoodSupply.htm (accessed May 2007).

21. Ag Bendech M, Chauliac M, Rérolle PG, Kante N \& Malvy DJM (2000) Les enjeux de la consommation alimentaire en milieu urbain à Bamako. Sante Publique 12, 45-63.

22. Torheim LE, Barikmo I, Hatloy A, Diakité M, Solvoll K, Diarra MM \& Oshaug A (2001) Validation of a quantitative food-frequency questionnaire for use in Western Mali. Public Health Nutr 4, 1267-1277.

23. Segovia-Siapco G, Singh P, Jaceldo-Siegl K \& Sabaté J (2007) Validation of a food-frequency questionnaire for measurement of nutrient intake in a dietary intervention study. Public Health Nutr 10, 177-184.

24. Coulibaly A, Turgeon-O'Brien H \& Galibois I (2007) Apports nutritionnels, caractéristiques anthropométriques et contrôle métabolique de diabétiques de type 2 à Bamako au Mali. Méd Nutr 43, 49-60.

25. McNaughton SA, Mishra GD, Bramwell G, Paul AA \& Wadsworth MEJ (2005) Comparability of dietary patterns assessed by multiple dietary assessment methods: results from the 1946 British birth cohort. Eur J Clin Nutr 59, 341-352.

26. Bureau des Sciences de la Nutrition (2001) Fichier canadien des éléments nutritifs. Ottawa: Ministère de la Santé Nationale et du Bien-être Social.

27. Barikmo I, Ouattara F \& Oshaug A (2004) Table de composition d'aliments $d u$ Mali. Lillestrøm, Norway: Akershus University College.

28. Wu L \& Busson J (1968) Table de composition des aliments à l'usage de l'Afrique. Rome: FAO.

29. BIO-RAD (2006) HPLC D-10 automat system. http:// diabetes.bio-rad.com $/ \mathrm{html} /$ products.html (accessed October 2006).
30. Rodriguez MM, Méndez H, Torun B, Schroeder D \& Stein AD (2002) Validation of a semi-quantitative food-frequency questionnaire for use among adults in Guatemala. Public Health Nutr 5, 691-698.

31. Thompson FE \& Byers $\mathrm{T}$ (1994) Dietary assessment resource manual. J Nutr 124, 2245S-2317S.

32. Willett WC (1994) Future directions in the development of food-frequency questionnaires. Am J Clin Nutr 59, 171S-174S.

33. Malekshah AF, Kimiagar M, Saadatian-Elahi M et al. (2006) Validity and reliability of a new food frequency questionnaire compared to $24 \mathrm{~h}$ recalls and biochemical measurements: pilot phase of Golestan cohort study of esophageal cancer. Eur J Clin Nutr 60, 971-977.

34. Goulet J, Nadeau G, Lapointe A, Lamarche B \& Lemieux S (2004) Validity and reproducibility of an intervieweradministered food frequency questionnaire for health French-Canadian men and Women. Nutr J 3, 1-10.

35. Nath SD \& Huffman FG (2005) Validation of a semiquantitative food frequency questionnaire to assess energy and macronutrient intakes of Cuban Americans. Int J Food Sci Nutr 56, 309-314.

36. Riley MD \& Blizzard L (1995) Comparative validity of a food frequency questionnaire for adults with IDDM. Diabetes Care 18, 1249-1254.

37. Schaefer EJ, Augustin JL, Schaefer MM, Rasmussen H, Ordovas JM, Dallal GE \& Dwyer JT (2000) Lack of efficacy of a food-frequency questionnaire in assessing dietary macronutrient intakes in subjects consuming diets of known composition. Am J Clin Nutr 71, 746-751.

38. MacIntyre UE, Venter CS \& Vorster HH (2000) A culturesensitive quantitative food frequency questionnaire used in African population: 2. Relative validation by 7-day weighed records and biomarkers. Public Health Nutr 4, 63-71.

39. Parr CL, Barikmo I, Torheim LE, Ouattara F, Kaloga A \& Oshaug A (2002) Validation of the second version of a quantitative food-frequency questionnaire for use in Western Mali. Public Health Nutr 5, 769-781.

40. Quandt SA, Vitolins MZ, Smith SL, Tooze JA, Bell RA, Davis CC, DeVellis RF \& Arcury TA (2007) Comparative validation of standard, picture-sort and meal-based foodfrequency qustionnaires adapted for an elderly population of low socio-economic status. Public Health Nutr 10, $524-532$.

41. Nthangeni G, Steyn NP, Alberts M, Steyn K, Levitt NS, Laubscher R, Bourne L, Dick J \& Temple N (2002) Dietary intake and barriers to dietary compliance in black type 2 diabetic patients attending primary health-care services. Public Health Nutr 5, 329-338.

42. Banini AE, Allen JC, Allen HG, Boyd LC \& Lartey A (2003) Fatty Acids, diet, and body indices of type II diabetic American Whites and Blacks and Ghanaians. Nutrition 19, $722-726$.

43. Schafer G, Schenk U, Ritzel U, Ramadori G \& Leonhardt U (2003) Comparison of the effects of dried peas with those of potatoes in mixed meals on postprandial glucose and insulin concentrations in patients with type 2 diabetes. Am J Clin Nutr 78, 99-103.

44. Diagana B, Akindès F, Savadogo K, Reardon T \& Staatz J (1999) Effects of the CFA franc devaluation on urban food consumption in West Africa: overview and cross-country comparisons. Food Policy 24, 465-478.

45. Gannon MC, Nuttall FQ, Lane JT \& Burmeister LA (1992) Metabolic response to cottage cheese or egg white protein, with or without glucose, in type II diabetic subjects. Metabolism 41, 1137-1145.

46. Gannon MC \& Nuttall FQ (2006) Control of blood glucose in type 2 diabetes without weight loss by modification of diet composition. Nutr Metab 3, 1-8. 